\title{
A framework for designing mathematics instruction using comics at the primary school level
}

\author{
Yun Li Lynnette Chu, Tin Lam Toh* \\ National Institute of Education, Nanyang Technological University, Singapore \\ *Corresponding author: tinlam.toh@nie.edu.sg
}

ARTICLE INFO

Article history:

Received: 3 July 2020

Revised: 11 July 2020

Accepted: 12 July 2020

Published online: 16 July 2020

Published regularly: October 2020

Keywords:

Comics, primary, mathematics

Education, fractions

\section{ABSTRACT}

Developing primary school students' interest in and getting them motivated to learn mathematics has been a perennial focus of educators. The use of comics for classroom instruction is an area gaining more attention from educators. In this paper, we review some existing education literature on the impact of comics on students' cognitive and affective learning needs. We also propose a TSCT (Theme, Storyline, Character, Text) framework for educators to design instructional material using comics for mathematics instruction in the primary mathematics classroom. With the TSCT framework, we demonstrate the design of one comics mathematics lesson on the topic of Fraction.

\section{Introduction}

Comics can be defined as a medium used to communicate ideas through contrasting pictures and images in a deliberate sequence (McCloud, 1993). Over the years, educators have started to realize the potential of using comics for classroom instruction (Sloan, 2009; Toh, 2009; Toh, Cheng, Lim \& Lim, 2019; Williams, 2008).

Compared to a traditional mathematics textbook, which is usually seen as a staid form of instructional material, teaching material using comics is likely to be more attractive and inviting for children. It is no doubt appealing to children and expected to be more successful in getting them motivated and excited to read mathematics (Toh, Chan, Cheng, Lim \& Lim, 2018). Research has also shown that motivation, cognition and emotion significantly affect children's perception of mathematics (Shmakov \& Hannula, 2010).

There is evidence that supports the use of comics as a teaching tool (Aiken, 2010; Aleixo \& Norris, 2007; Cheesman, 2006; Sloan, 2009; Williams, 2008). Numerous studies have been conducted to study the impact of comics on learning mathematics by university students (Cho, 2007; Cho, Osborne, Sanders, 2015). However, the idea of comics instructional material replacing the traditional textbooks in the primary school mathematics classroom has not received much attention. Many teachers and parents still believe that comics are meant for fun and leisure and hence are not suitable for serious content teaching (Cleaver, 2008). However, students in the future are likely to encounter educational material in multimedia presentations that involve a

To cite this article:

Chu, Y. L. L. \& Toh, T. L. (2020). A framework for designing mathematics instruction using comics at the primary school level. JRAMathEdu (Journal of Research and Advances in Mathematics Education), 5(3), 218230. doi: https://doi.org/10.23917/jramathedu.v5i3.11373 
combination of texts and colorful graphics (Hartley, 2004). Even the mathematics textbooks today contain more graphics, visuals and even comic strips. Thus, it is not too far-fetched that comics can one day be used as a "mathematics textbook" for students.

Comics have been found to be effective in teaching Science and English at the primary schools (Aleixo \& Norris, 2007; Farinella, 2018). However, studies that have been conducted on how comics can serve as an effective teaching tool for primary school mathematics are relatively scarce. To many students, mathematics can be a tedious or even daunting subject which contains many rules and formulae. We believe that, just like what has been done by Toh, Cheng, Lim and Lim (2019) for teaching mathematics at the secondary level, comics can be used to demonstrate to students the more light-hearted aspects of Mathematics and pique students' interest in Mathematics (Toh, Cheng, Lim \& Lim, 2019). In this paper, we propose a set of guiding principles for designing comics for mathematics instruction. With the guiding principles, we design one comics lesson on the topic of Fraction with the details of the lesson enactment provided.

\section{Benefits of Comics for Education}

Many studies have asserted that comics appeal to children at the primary school level (Pelton \& Pelton, 2009). This observation concurs with our collective classroom experience with young children. A survey of the existing education literature shows that many studies discuss the many benefits of comics for education. We broadly classify the categories of advantages in the following subsections.

\section{Spatial Contiguity Effect}

One benefit brought out by researchers on the benefits of comics on student learning is the spatial contiguity effect. It means that people learn better and more when words and pictures are displayed spatially near to each other. Many studies have shown that including words in images can lead to higher comprehension compared to when words and images are -presented separately (Mayer, 2003; Mayer, Steinhoff, Bower, \& Mars, 1995; Moreno \& Mayer, 1999). Spatial contiguity can help make a clearer connection between text and image components, thereby promoting active learning (Mayer, 2003). Conducting a metaanalysis, Ginns (2006) discovered that the greater the spatial contiguity of text and images, the more significant the increase in learning effectiveness.

The spatial contiguity found in comics, therefore, will greatly help students understand the mathematical concepts as the texts and images in comics are close to each other compared to traditional textbooks. In addition to that, the numerous panels used in comics also facilitate students' learning experience in the subject by highlighting important information in separate panels (Mayer \& Gallini, 1990). These panels in the comics break down concepts into smaller segments which facilitate students' understanding. This was described as the "braiding process" by Groensteen (2007). In addition, apart from the pictorial illustrations and texts, the reader also gains an understanding of each panel and the entire storyline through its translinear relationships with the surrounding panels.

Visual representations found in comics, thus help make concepts more concrete and simpler for students to comprehend. They help students to understand the concepts in more than one modality, which enhances learning. Based on Piaget's theory of cognitive development, most primary school students (Grades 1 to 6) are at the Concrete Operational Stage, where their minds are still not ready for abstract thinking. Hence, they are not ready for abstract mathematics concepts. Thus, comics 
concretize the abstract mathematics concepts through its use of a combination of texts and visuals.

\section{Comics Facilitates Information Retention in Students}

According to neurologists, human beings process text and images in different parts of the brain. By processing text and images together, humans can recall faster and learn better as different parts of the brain are activated simultaneously. This is commonly known as the Dual-Coding Theory of Cognition (Paivio, 1986). A study by Aleixo and Sumner (2017) suggests that image with text results in greater memory retention compared to text-only. This is further confirmed with a research study on Primary School students by Smith, Goodmon, Howard, Hancock, Hartzell, and Hilbert (2019). Smith et al. suggest that the use of images with text may be an effective pedagogical supplement for primary school students and, in particular, for dyslexic students. This is also congruous to Mayer (2009) that students learn better from a combination of visuals and texts than purely text, which Mayer (2009) termed as the multimedia effect. Hence, it follows as a corollary that using comics to teach Mathematics will allow students to learn a particular concept faster and better.

Through the comics' narration, the students are more easily impressed and have a lasting impression with the mathematics concepts conveyed through the comics. Stories involving the fictitious characters, the story plot and the humor associated with the comics are more memorable than the usual mathematical rules to the students (Martin, 2007; Özdemir, 2017). The narration in the comics offers a "subliminal" route to learning mathematics. The use of fictitious characters that the students can associate with help encode information and increase their cognitive effort (Jee \& Anggoro, 2012). There are also many studies showing that the use of humor in comics aids in information retention by illustrating key points (Bolton-Gary, 2012; Martin, 2007).

\section{Comics Addresses The Affective Need of Student Learning}

Children of school-going age often take delight in delving into comics for entertainment (Pelton \& Pelton, 2009). Polls conducted by Davis and Brember (1993) and Worthy, Moorman, and Turner (1999) found that comics ranked high among primary school students' favorite reading lists. Ziv (1988), Schmidt and Williams (2001), and Schmidt (2002) found increased learning in students when humor is effectively used in comics. The clever interweaving of humor, relatable characters, and an interesting plot found in comics motivate students to learn the mathematical concepts subconsciously as they enjoy interacting with the content in the comics. Coupled with the relaxed environment conducive afforded by comics for learning, learning math comics' content daunting to students (Bolton-Gary, 2012; Martin, 2007). This helps to reduce students' anxiety (Whyte \& Anthony, 2012).

\section{Comics is Especially Helpful for Dyslexic Students}

Hallenbeck $(\underline{1976})$ posited that comics could also be used as a teaching medium for students with learning difficulties. He highlighted that students with dyslexia and similar educational needs benefit from the left-to-right arrangement of panels in comics; easy-toread capital letter fonts and symbols and contextualization to aide their understanding. Students with dyslexia often struggle in mathematics as they find it challenging to understand lengthy texts in textbooks. The left-to-right arrangement of comics teaches dyslexic children left-to-right progression (Hallenbeck, 1976) and helps them understand the concepts taught. The succinct word diction found in comics can also help them 
discriminate the key concepts, allowing them to grasp the concepts more easily. Studies also found that students with learning difficulties tend to learn better when presented with upper case plain fonts (Hallenbeck, 1976). This is frequently found in the word balloons of children's comics. The fonts Sans serif, Roman, and mono spaced fonts, which are typically used in comics, have been found to help those with dyslexia read better (Baeza-Yates \& Rello, 2013). Hence, the organization and structure of comics will be particularly beneficial to dyslexic students. This, in turn, facilitates their understanding of the mathematics content conveyed by the comics.

\section{Caution on The Use of Comics}

Educators must be cognizant of several possible limitations on the use of comics for classroom instruction in primary school, even though numerous benefits have been presented in the preceding subsections. Firstly, the comics narrative nature may cause students to make incorrect inferences from the text if they are left to read independently without the scaffolding of the teachers (Jee \& Anggoro, 2012). In short, the role of the classroom teacher as a facilitator is crucial in the mathematics lessons.

Secondly, if the students are not able to associate themselves with the comics' characters, they are not likely to be motivated to read the comics (and to participate in the mathematics discourse therein). Further, it also reinforces stereotypes (Jee \& Anggoro, 2012). It should also be noted that not all students love comics: if comics is the only approach used to teach mathematics, some students may be repelled by the mathematics lessons, resulting in them disliking the subject. Perhaps the use of comics for mathematics instruction under the setting of differentiated instruction is a plausible setting.

In conclusion, one cannot deny the many benefits that comics can bring as an effective teaching tool. These benefits could potentially be even more pronounced for primary school students as children of this age group tend to love comics. However, educators need to be cognizant of the potential limitations that could arise if comics resources totally replace traditional mathematics instructional materials.

\section{Methodology}

In this paper, we review existing education literature on the usage of comics in teaching for Primary school students, and educational theories related to the learning mathematics by Primary school students. Altogether, 53 information sources (Secondary Literature) were reviewed from a diverse range, including journal articles, books, papers and newspaper articles. The search techniques used were block building and citation searching, with the keywords being "comics", "Primary Mathematics", "education". We have presented a summary of the potential benefits and limitations of comics for mathematics classroom instruction in the preceding section. We next propose a set of guiding principles for designing comics for mathematics instruction at the primary level.

\section{Guiding Principles in Designing Comics for Teaching Primary Mathematics}

In this section, we present some proposed guiding principles, based on the above literature review, about designing comics to teach Primary Mathematics.

\section{Interesting Storyline and Relatable Characters}

Comics should have a storyline and characters which the students can associate. This is to pique students' interests so that they will be motivated to read on. In particular, by including characters that are relatable by the students, the cognitive 
effort and memory formation via information encoding through self-reference by the readers can be very much enhanced (Jee \& Anggoro, 2012). The reader's ability to connect with the fictitious characters in the comics could motivate them to set aside more time and cognitive resources to understand the story and, hence, the concepts interweaved in the story plot. If the students can associate the comics' storyline, it could also provide the students a platform for self-reference- relating the storyline back to themselves - resulting in greatly entrenched memories (Symons \& Johnson, 1997).

\section{Humor}

Infusing humor into comics (both in the storyline and the visual arts) helps to draw students to read the comics and learn the mathematical concepts embedded inside the comics. In fact, humor not only helps students remember concepts better but also helps create a conducive learning environment as it generates a less threatening learning atmosphere. Further, many studies have found a close relationship between information processing and instructional humor (Segrist \& Jupp, 2015). In addition, it has been found that humor helps improve memory retention rate (Lujan \& DiCarlo, 2016; Kaplan \& Pascoe, 1977; Schmidt, 2002), decrease Mathematics anxiety (Whyte \& Anthony, 2012), and motivate students (Martin, 2007) to learn the mathematics concepts.

\section{The Visual and Text Presentation of The Comics}

The text has to be succinct, using sufficiently large fonts. Usually, capital letter fonts are used in the comics. Regarding the relative position of the visual and the text, it was noted that the spatial contiguity effect tends to be greater if the words are situated beside the image compared to when placed beneath the image (Moreno \& Mayer, 1999).

As the use of comics might likely benefit dyslexic students (Toh et al., 2017), it is recommended that dyslexia-friendly fonts such as Arial, Courier, Computer Modern Unicode, Helvetica and Verdana be used for designing the comics instructional package. Such fonts are found to enhance the reading performance and hence increase comprehensibility for people with dyslexia. Italic fonts should not be used in comics as they are found to negatively affect the reading performance of dyslexic people (Baeza-Yates \& Rello, 2013). Many dyslexic students struggle in learning mathematics (Jordan, 2007; Salihu, Aro \& Räsänen, 2018) as they have reading disabilities. Thus, they are likely intimidated by the large chunks of texts found in the traditional mathematics textbooks, resulting in them not being able to comprehend the various mathematics concepts (Landerl, Fussenegger, Moll \& Willburger, 2009). Thus, fonts' choice is an important factor for consideration when designing comics instructional package for teaching primary mathematics.

\section{A Framework for Designing Comics as Instructional Material}

Based on the literature review that we have described in the preceding subsections, we propose the TSCT (Theme, Storyline, Character, Text) framework for designing instructional material using comics for primary school mathematics classroom instruction.

\begin{tabular}{|c|c|}
\hline Theme & : Relatable and Age-appropriate \\
\hline$\underline{\text { Sttoryline }}$ & : Interesting, infused with humor \\
\hline Characters & : Relatable but not too many characters in the comics \\
\hline Text & : - Succinct \\
\hline
\end{tabular}


- Key concepts must be explicit

- Font size must be sufficiently large for visibility

- Use dyslexia-friendly fonts: Arial, Courier, Helvetica, Verdana, Computer Modern Unicode (capital letters), no italics.

\section{Designing a Set of Comics for One Lesson on Comparing Unlike Fractions}

In this section, we demonstrate designing a set of comic strips for teaching one lesson on fractions at the primary five levels (comparing unlike fractions). This subtopic of fractions is considered a challenging topic for many students (Van Steenbrugge, Valcke \& Desoete, 2010). Next, we present our rationale for the design process and highlight the key features based on the guiding principles proposed.

\section{Theme}

We chose a superhero theme for the comics as most primary school children are fascinated by superheroes due to the influence of the media and the popular culture. Most primary school children are fascinated by the superheroes' powers and how they fight the world of injustice. According to Sousa and Schneiderman (1986), the need to feel empowered is among the several factors that could have contributed to the substantial attraction of superheroes to young children. Many children feel overwhelmed by the demands of their parents, teachers, school, and society. Therefore, they desire to be like their superheroes who can take charge of difficult situations and hence not feel powerless.

Another advantage of using superheroes is that they are timeless-they are popular among children, whether the setting is in the past, present or future. This resulted in the superheroes being ideal teaching tools (O'Roark, 2017). Based on the data released from the Motion Picture Association of America, films based on characters from comics have snagged the most earnings since 2013. For example, Iron Man 3 and Guardians of the Galaxy grossed the most earnings in 2013 and 2014, respectively (Motion Picture Association of America, 2015). Every week, many millions of people tune in to television broadcasts of both animated and live-action superheroes. The use of superheroes in comics to teach should, therefore, not be underestimated. In our design of comics, superheroes are used to pique the children's interest in mathematics. For this comics lesson on Fractions, we created the setting of two fictitious superhero characters Aquarius and Bionics, who live on Planet Aurelli. They are the Planet Earth caretakers and their job is to help solve the problems on Earth. In the course of their mission on Earth, they need to tackle various mathematics concepts to accomplish their tasks to ensure their own survival. The mathematics concepts are thus subtly interweaved into the storyline and adds a contextualized dimension to it. Through this, we also hope to bring across the message that mathematics is found everywhere and applicable to the real world.

\section{Storyline}

To accompany the superhero theme and mathematical concepts involved, the storyline of the story incorporates environmental issues in order to raise students' awareness of the environmental problems the world is currently facing. Even though environmental health education is increasingly becoming a global priority, it still receives insufficient attention in schools. This is surprising as the classroom would be a natural place to imbibe and rally students to do their part for the environment. Learning about the environment provides students the platform to understand how 
nature works and how human actions have impacted the environment (Jeronen, Jeronen, \& Raustia, 2009). It is interesting to note that teachers view environmental health as an important topic that students should know. Yet, they tend to cite obstacles of infusing environmental issues into the curriculum, such as the lack of curriculum time to fit this into the packed curriculum (Keselman, Levin, Kramer, Matzkin \& Dutcher, 2011). We thus propose to ride on the affordance of comics to infuse environmental issues into the storyline. This could provide opportunity for teachers to raise their students' awareness of the various environmental issues infused into a mathematics lesson. Here, the ramification of climate change due to human activity is represented by the bleaching of the corals in the Great Barrier Reef, one of the seven natural wonders of the world. We hope that this conscious effort to foster environmental sensitivity will contribute to raising a generation that are eco-conscious and good stewards of our environment.

Humor was infused into the comics in order to increase the entertainment factor and promote a light-hearted learning environment. For example, the absurd image of a half ice cream cone as Aquarius haggled with the stall owner was included in the comics. The positive learning gains when humor helps students grasp and remember mathematical concepts better (Segrist \& Jupp, 2015).

\section{Characters}

In order to avoid excessive "noise" in the communication process, we created only two superhero characters in this set of short comics - Aquarius and Bionics. The names and supernatural ability of the two superheroes were chosen to reflect the Earth's environmental issues. The superhero Aquarius takes care of Earth's water bodies - oceans, lakes, and rivers, and has supersonic ears to hear the marine lives groaning in the polluted environment they live in. The character Bionics has bionic eyes which can see far into the distance. Bionics is also mathematically inclined so that both superheroes are able to complete their various rescue missions on Earth by solving real-world mathematics problems. On the other hand, Aquarius, the nature healer, is weak in Mathematics. This creates a contrast and allows more vulnerable students to identify with her as they too may have the same mathematical misconceptions as Aquarius. This choice of a contrasting pair of characters used in the comics is similar to the consideration taken in the design of the comics package constructed by Toh, Cheng, Jiang, and Lim (2016). A draft of the first half of the comics for the lesson is included in the Appendix as an illustration.

Text

We have discussed the text presentation in the above section (including the font size and types of fonts), which we will not elaborate further. In particular, we took note that the text in the comic strips must address prominent student misconceptions.

\section{Addressing Students' Misconception}

Many primary school students have various misconceptions about fractions. These misconceptions can result from interference from algorithms about whole numbers, or conceptual ones (Edge, 2007, pp. 147 - 148). A common misconception among students about fractions is the result of interference from their knowledge about whole numbers the comparison of unit fractions (with numerator 1). Many students tend to think that the larger the denominator, the larger the unit fractions. This is because they have learnt previously that in the case of like fractions, the bigger the numerator, the bigger the Fraction. In this comic strip, we included one plot as an 
attempt to address this misconception through the conversation of Aquarius and Bionics (Figure 1). They had to use their mathematics knowledge to get the biggest pizza slice with a coupon found on the grounds of a carnival. Bionics acts as the more knowledgeable other and explains in simple terms how to compare unit fractions to Aquarius.

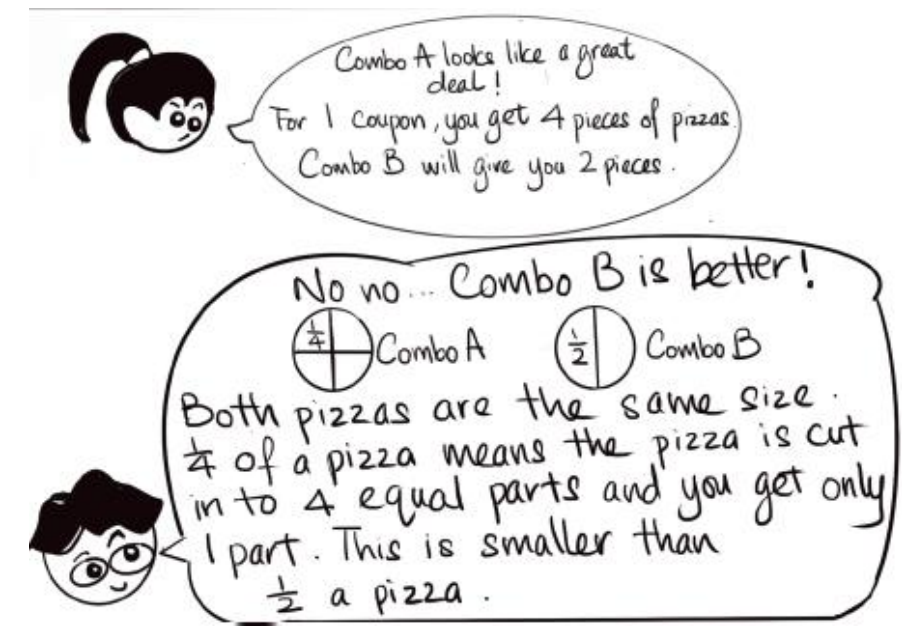

Figure 1. An illustration of comparing fractions in the comic strip (draft).

\section{Discussion}

The comics' creation is to encourage students to actively engage in mathematical discourse through their interaction with the contextualized content in the comics. Compared to traditional textbooks which usually have long texts with images and texts separate, the information presented in comics is much shorter, carefully worded, and embedded in images, thereby bringing across the important concepts more clearly and effectively. In addition, the inclusion of humor, a feature found in comics, will likely make the teaching of fractions more appealing to the primary school children.

The superhero theme was specifically chosen to relate to Primary School students. The element of absurdity -superheroes recharged by eating pizzas- was also incorporated to help students remember the storyline and mathematical concepts better. They follow the story plot and the actions and thoughts of the superheroes as they read the comics.

Learning through comics will also help students grasp the important $21^{\text {st }}$-century skill of deciphering information from the combination of text and images (Lowrie ,2012). This is particularly important as it aligns with the objective of most education ministries in the world to prepare their students for key challenges of a changing and dynamic world (Toh, Cheng, Ho, Jiang \& Lim, 2017).

\section{Conclusion}

This paper reviewed existing literature on using comics for education and proposed the general guidelines of designing a comics instructional package for teaching primary school mathematics. We designed a set of comic strips for teaching a subtopic of fractions as an exemplar of applying the guidelines we proposed (a draft of the first half of the comic strips is shown in the Appendix). The use of comics to teach mathematics, especially the relatively challenging topics within the curriculum, helps create an engaging and nonthreatening, conducive learning environment for Primary School students. Comics 
specifically was written for Mathematics teaching; therefore, it could be more effective than traditional Mathematics textbooks in bringing across difficult mathematical concepts to Primary School students. However, we have yet to trial the comic lesson in the authentic mathematics classroom due to time constraints.

Comics hooks students' interest in learning mathematics through interactive nature and the relatively simple language used. Not only that, but it also helps to stretch students' thinking through the introduction of contextualized mathematics. This is aligned to the latest mathematics education trend in engaging students with mathematics problems in a real-world context. In conclusion, there is great potential for comics to be used as a teaching medium in Primary School Mathematics. Hopefully, this paper will spur further interest educators in exploring the use of comics for mathematics instruction, especially for primary school children.

\section{Acknowledgment}

We would like to acknowledge the funding support from Nanyang Technological University - URECA Programme for this research project. We would like to thank the illustrator, Ms. Alison Ang, for generously offering to provide a first draft sketch of part of the comics that is presented in this paper.

\section{Bibliography}

Aiken, K. (2010, April). Superhero History: Using comic books to teach U.S. history. OAH Magazine of History, 24(2), 41-47. https://doi.org/10.1093/maghis/24.2.41

Aleixo, P., \& Norris, C. (2007). Comics, Reading and Primary Aged Children. Education \& Health, 25(4), 70-73.

Aleixo, P., \& Sumner, K. (2017). Memory for biopsychology material presented in comic book format. Journal of Graphic Novels and Comics, 8(1), 79-88. https://doi.org/10.1080/21504857.2016.1219957

Baeza-Yates, R., \& Rello, L. (2013). Good Fonts for Dyslexia. Retrieved from http://dyslexiahelp.umich.edu/sites/default/files/good fonts for dyslexia study.pdf

Bolton-Gary, C. (2012). Connecting Through Comics: Expanding Opportunities for Teaching and Learning. US-China Education Review B, 4 (2012), 389 - 395. https://files.eric.ed.gov/fulltext/ED533545.pdf

Cheeseman, K. (2006). Using Comics in the science classroom. Journal of College Science Teaching, 35(4), 48-51.

Cho, J. Y. (2007). Engineering Math? How about it in Comics? Gyeongsang: KyoWooSa.

Cho, H., Osborne, C., \& Sanders, T. (2015). Classroom experience about cartooning as assessment in pre-service Mathematics content course. Journal of Mathematics Education at Teachers College, 6, 45-53. https://doi.org/10.7916/jmetc.v6i1.609

Cleaver, S. (2008). Comics and graphic novels. Instructor, 117 (6), 28 - 30.

Davies, J., \& Brember, I. (1993). Comics or stories? Differences in reading attitudes and habits of girls and boys in years 2, 5, and 6. Gender and Education, 5, 305-319. https://doi.org/10.1080/0954025930050306

Edge, D. (2007). Teaching of fractions. In P. Y. Lee (Ed.), Teaching primary school mathematics: A resource book (pp. 130 - 154). Singapore: McGraw-Hill.

Farinella, M. (2018). The potential of comics in science education. Journal of Science Communication, 17 (01), Y01. https://doi.org/10.22323/2.17010401 
Ginns, P. (2006). Integrating information: A meta-analysis of the spatial contiguity and temporal contiguity effects. Learning and Instruction, 16(6), 511-525. https://psycnet.apa.org/doi/10.1016/j.learninstruc.2006.10.001

Groensteen, T. (2007). The System of Comics. University Press of Mississippi.

Hallenbeck, P. N. (1976). Remediating with comic strips. Journal of Learning Disabilities, 9(1), 22-26. https://doi.org/10.1177\%2F002221947600900102

Hartley, J. (2004). Designing instructional and informational text. In D. H. Jonassen (Ed.) Handbook of Research in Educational Communications and Technology (2nd ed.) (pp. 917-947). Mahwah, N.J.: Erlbaum.

Kaplan, R.M., \& Pascoe, G.C. (1977). Humorous Lectures and Humorous Examples: Some effects upon Comprehension and Retention. Journal of Educational Psychology, 69(1), 61-65. https://psycnet.apa.org/doi/10.1037/0022-0663.69.1.61

Keselman, A., Levin, D. M., Kramer, J. F., Matzkin, K., \& Dutcher, G. (2011). Educating Young People about Environmental Health for Informed Social Action. Umwelt und gesundheit online, 4, 1-8.

Jee, B. D., \& Anggoro, F. K. (2012). Comic cognition: Exploring the potential cognitive impacts of science comics. Journal of Cognitive Education and Psychology, 11(2), 196208. https://doi.org/10.1891/1945-8959.11.2.196

Jeronen, E., Jeronen, J., \&Raustia, H. (2009). Environmental Education in Finland-A Case Study of Environmental Education in Nature School. International Journal of Environmental and Science Education, 4 (1), 1-23. https://eric.ed.gov/?id=EJ884383

Jordan, N. C. (2007). Do words count? Connections between mathematics and reading difficulties. In D. B. Berch \& M. M. M. Mazzocco (Eds.), Why is math so hard for some children? The nature and origins of mathematical learning difficulties and disabilities (pp. 107-120). Paul H Brookes Publishing. https://psycnet.apa.org/record/2007-03663-006

Landerl, K., Fussenegger,B., Moll, K., \& Willburger, E. (2009). Dyslexia and Dyscalculia; Two Learning Disorders With Different Cognitive Profiles. Journal of Experimental Child Psychology, 103, 309-324. https://doi.org/10.1016/j.jecp.2009.03.006

Lowrie, T. (2012). Visual and Spatial Reasoning: The Changing Form of Mathematics Representation and Communication. In T.L. Toh, \& B. Kaur (Eds.), Reasoning, communication and connections in mathematics: Yearbook 2012, Association of Mathematics (pp. 149-168). Singapore: World Scientific Publishing. https://doi.org/10.1142/8466

Lujan, H.L., \& DiCarlo, S.E. (2016). Humor promotes learning! Advances in physiology education, 40(4), 433-434. https://doi.org/10.1152/advan.00123.2016.

Martin, R. (2007). The psychology of humor. Burlington, Massachusetts: Elsevier Academic Press.

Mayer, R. E. (2003). The promise of multimedia learning: Using the same instructional design methods across different media. Learning and Instruction, 13(2), 125-139. https://doi.org/10.1016/S0959-4752(02)00016-6

Mayer, R. E. (2009). Multimedia learning (2nded.). Cambridge University Press.

Mayer, R. E. \& Gallini, J. K. (1990). When is an illustration worth ten thousand words? Journal of Educational Psychology, 82(4), 715-726. https://doi.org/10.1037/0022$\underline{0663.82 .4 .715 .}$.

Mayer, R.E., Steinhoff, K., Bower, G., \& Mars, R. (1995). A generative theory of textbook design: Using annotated illustrations to foster meaningful learning of science text. Educational Technology Research and Development, 43(1), 31-44. https://doi.org/10.1007/BF02300480 
McCloud, S. (1993), Understanding Comics: The Invisible Art, New York, NY: Harper Collins

Moreno, R., \& Mayer, R. E. (1999). Cognitive principles of multimedia learning: The role of modality and contiguity. Journal of Educational Psychology, 91(2).358-368. https://psycnet.apa.org/doi/10.1037/0022-0663.91.2.358

Motion Picture Association of America. (2015, March 11). Theatrical market statistics 2014. http://www.mpaa.org/wp-content/uploads/2015/03/MPAA-Theatrical-MarketStatistics-2014.pdf

O'Roark, B. (2017). Super-economics man! Using superheroes to teach economics. Journal of Economics Teaching, 2(1), 51-67.

Ozdemir, E. (2017). Humor in elementary science: Development and evaluation of comic strips about sound. International Electronic Journal of Elementary Education, 9, 837850. https://iejee.com/index.php/IEJEE/article/view/288

Paivio, A. (1986). Mental Representations: A Dual-Coding Approach. New York: Oxford University Press.

Pelton, F. L., \& Pelton, T. (2009). The Learner as Teacher: Using Student Authored Comics to "Teach" Mathematics Concepts. In G. Siemens \& C. Fulford (Eds.), Proceedings of EDMEDIA 2009--World Conference on Educational Multimedia, Hypermedia \&Telecommunications (pp. 1591-1599). Honolulu, HI, USA: Association for the Advancement of Computing in Education (AACE).

Salihu, L., \& Aro, M., \& Räsänen, P. (2018). Children with learning difficulties in mathematics: Relating mathematics skills and reading comprehension. Issues in Educational Research, 28 (4), 1024-1038. Retrieved from http://www.iier.org.au/iier28/salihu.pdf

Schmidt, S. R., (2002). The humour effect: Differential processing and privileged retrieval, Memory, 10(2), 127-138. https://doi.org/10.1080/09658210143000263

Schmidt, S., \& Williams, A. (2001). Memory for humorous cartoons. Memory and Cognition, 29(2), 305-311. https://doi.org/10.3758/BF03194924

Segrist, D. J., \& Jupp, S. D. (2015). This class is a joke? Humor as a pedagogical tool in the teaching of psychology. Psychology Teacher Network: American Psychological Association, 25, 14-15.

Shmakov, P., \& Hannula, M.S. (2010) Humour as means to make mathematics enjoyable. In V. Durand-Guerrier, S. Soury-Lavergne, \& F. Arzarello (Eds.), Proceedings of the Sixth Congress of the European Society for Research in Mathematics Education (pp. 144153). Retrieved from http://www.inrp.fr/editions/cerme6

Sloan, W. M. (2009). No laughing matter: Comic books have serious educational value. Education Update, 51(10), 1-3, 7.

Smith, P. L., Goodmon, L. B., Howard, J. R., Hancock, R, Hartzell, K. A. \& Hilbert, S. E. (2019). Graphic novelisation effects on recognition abilities in students with dyslexia. Journal of Graphic Novels and Comics, 1-18. https://doi.org/10.1080/21504857.2019.1635175

Sousa, C., \& Schneiderman, J. (1986). Preschoolers and superheroes-A dangerous duo. Early Years, 17, 75-77.

Steenbrugge, H. V., Valcke, M., \& Desoete, A. (2010). Mathematics learning difficulties in primary education: teachers' professional knowledge and the use of commercially available learning packages. Educational Studies, 36(1), 59-71. https://doi.org/10.1080/03055690903148639

Symons, C. S., \& Johnson, B. T. (1997). The self-reference effect in memory: A meta-analysis. Psychological Bulletin, 121(3), 371-394. https://psycnet.apa.org/doi/10.1037/00332909.121.3.371 
Toh, T.L. (2009). Use of cartoons and comics to teach algebra in mathematics classrooms. In Martin, D., Fitzpatrick, T., Hunting, R., Itter, D., Lenard, C., Mills, T., Milne, L. (Ed.), Mathematics Of Prime Importance: MAV Yearbook 2009 (pp. 230 - 239). Melbourne: The Mathematical Association of Victoria.

Toh, T. L., Chan, C. M. E., Cheng, L. P., Lim, K. M., \& Lim, L. H. (2018). Use of comics and its adaptation in the mathematics classroom. In P.C. Toh, \& B.L. Chua (eds.), Mathematics instruction: Goals, tasks and activities (pp. 67-86). Singapore: World Scientific Publishing. https://doi.org/10.1142/9789813271678 0005

Toh, T. L., Cheng, L. P., Ho, S. Y., Jiang, H., \& Lim, K. M. (2017). Use of comics to enhance students' learning for the development of the 21st century competencies in the mathematics classroom. Asia Pacific Journal of Education, 37(4), 437-452. https://dx.doi.org/10.1080/02188791.2017.1339344

Toh, T. L., Cheng, L. P., Jiang, H., \& Lim, K. M. (2016). Use of comics and storytelling in teaching mathematics. In P. C. Toh, \& B. Kaur (Eds.), Developing 21st Century Competencies in the Mathematics Classroom, Yearbook 2016, Association of Mathematics Educators (pp. 241-260). Singapore: World Scientific Publishing. https://doi.org/10.1142/9789813143623 0013

Toh, T. L., Cheng, L. P., Lim, L. H., \& Lim, K. M. (2019). Shopaholics needs mathematics too! Teacher and student perceptions of the use of comics to teach percentage. Australian Mathematics Education Journal, 1(1), 17-23. https://search.informit.com.au/documentSummary;dn=338697223376888;res=IEL $\underline{\text { HSS }}$

Toh, T. L., \& H. W. E. Lui. (2014). Helping Normal Technical Students with Learning Mathematics - A Preliminary Survey. Learning Science and Mathematics Online Journal, 2014(1), 1-10.

Van Steenbrugge H., Valcke, M., \& Desoete, A. (2010). Mathematics learning difficulties in primary education: Teachers' professional knowledge and the use of commercially available learning packages. Educational Studies, 36(1), 59-71. https://doi.org/10.1080/03055690903148639

Whyte, J. \& Anthony, G. (2012). Maths anxiety: The fear factor in the mathematics classroom. New Zealand Journal of Teachers' Work, 9(1), 6-15.

Williams, R. M. (2008). Image, text, and story: Comics and graphic novels in the classroom. Art Education, 61(6), 13-19. https://doi.org/10.1080/00043125.2008.11652072

Worthy, J., Moorman, M., \& Turner, M. (1999). What Johnny likes to read is hard to find in school. Reading Research Quarterly, 34, 12-27. https://doi.org/10.1598/RRQ.34.1.2

Ziv, A. (1988). Teaching and learning with humor. Journal of Experimental Education, 57, 515. https://doi.org/10.1080/00220973.1988.10806492 


\section{APPENDIX}

A segment of the first draft of the comic strips (illustrated by Ms Alison Ang)
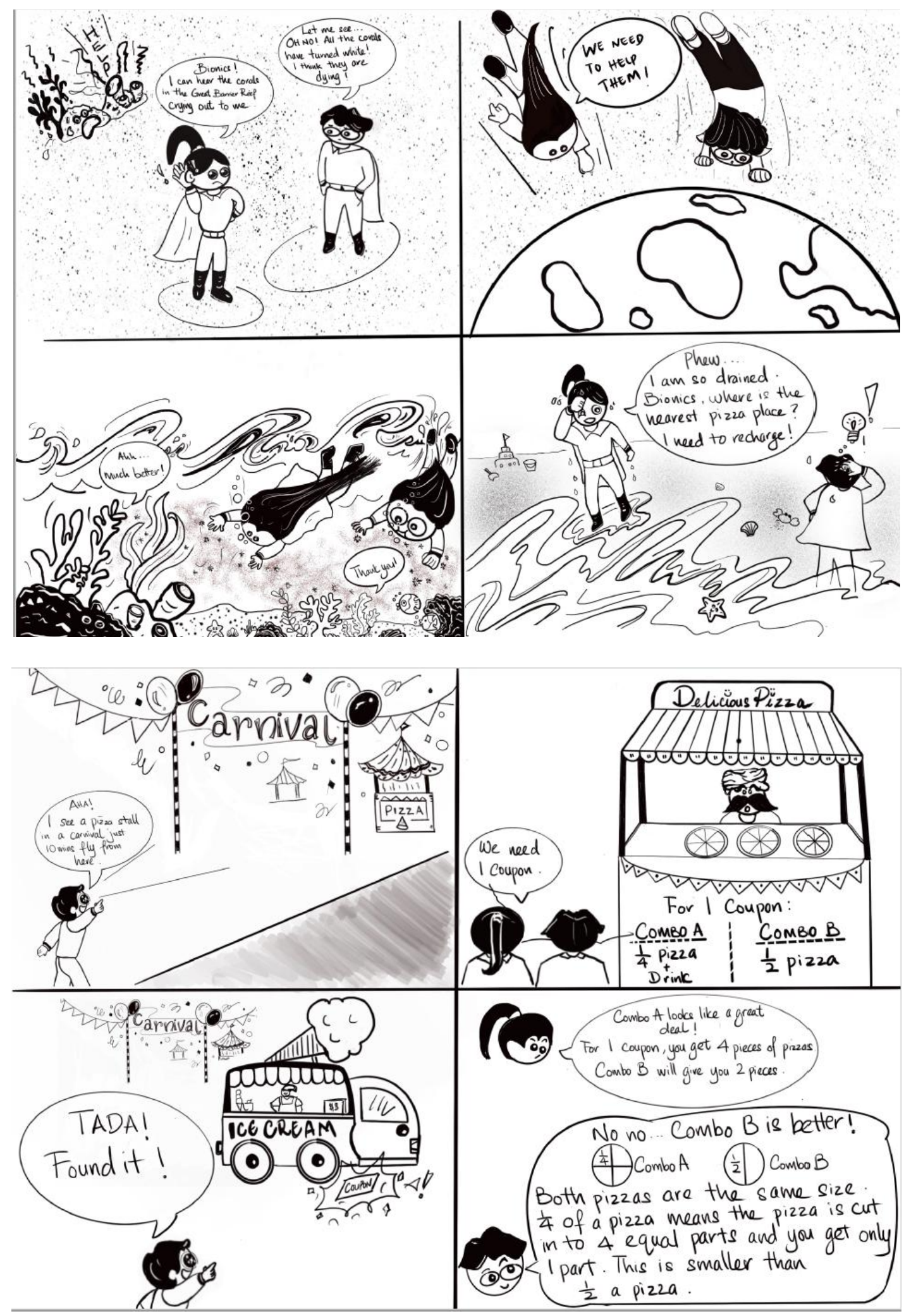